\title{
Human Problems in Remy Sylado Mbeling Poetry: the Analysis of Norm Srata by Ingarden
}

\author{
Irfai Fathurohman ${ }^{1}$, Teguh Supriyanto ${ }^{2}$, Agus Nuryatin ${ }^{3}$ and Subyantoro ${ }^{4}$ \\ ${ }^{1}$ Graduate School Language Education, Universitas Negeri Semarang, Indonesia. \\ ${ }^{2,3}$ Literature at Graduate Language Education, Universitas Negeri Semarang, Indoneisa \\ ${ }^{4}$ Psycholinguistic at Graduate Language Education Semarang State University. \\ ${ }^{1}$ Corresponding email: irfai.fathurohman@umk.ac.id;
}

\begin{abstract}
Human problems from various aspects of life such as freedom in behaving, choosing, and voicing aspirations tend to experience limitations that are not because of the rules that curb themselves both in writing and oral. The purpose of this study first, describe the structure of Remy Sylado's mbeling poem. Secondly, knowing the human problems in Remy Sylado's mbeling poem. This research method that is qualitative descriptive. Data and data sources is a collection of Remy Sylado mbeling poems published by KPG (Kepustakaan Populer Gramedia) in 2004. Data collection techniques use recording on paper data. Data analysis used the theory of strata norm analysis of Ingarden. The results of this study first found that Remy Sylado's mbeling poem contained anonymity and alliteration, climactic majesty, irony majesty, and parable exhortations tend to exist in Remy Sylado's mbeling work, vision imagery, motion imagery, auditory images appearing in mbeling poems. Second, human problems from the social, humanitarian, and freedom of expression are attached to the mbeling poem. This problem is dominated by the desire to provide changes to the symptoms that are considered harmful and not create new innovations. The well-established elements that arise because of the rules in writing and the confidence that exist in a person triggers a conflict that occurs directly or indirectly.
\end{abstract}

Keywords: Human Problems, Establishments, Mbeling Poems by Remy Sylado, Strata Norma Ingarden.

\section{Introduction}

The issue of human interest and interesting to be reviewed, known, and used as an evaluation and consideration by the next era. In every age, humans have their ideas, ideas, and existence to update, supplement and create important concepts in response to the needs both in scholarship, habits, actions that must have failed progress. The stagnant phenomena of human life are spurred by various considerations such as the existence of rules that curb the freedom of human beings in expression, the power that governs every human action, the prolonged imitation, the absence of media that supports the change. These symptoms lead to the accumulation of problems faced by humans and not necessarily resolved properly. Every human chosen path exists that affects both of itself determining the choice and support of others that make human choices. The losses caused by this choice make people alienated, cornered, and under pressure both directly and indirectly. Sugiarti (2013:2) put forward as a result of the process of impression, creation, and imagination, literature has an important role in human life, because literature has a "dulce et utile function" (fun and useful) for the reader.

Literary works as part of the culture record well and carefully about the symptoms of human problems in accordance with the era and era. Poetry as one of the creation of literary works reveals the problems experienced by humans and provides a perspective to be addressed and reviewed more deeply. Poems like this tend to put forward the message, the problems, the solutions that tend to be different from other types of poetry. The conflicts in this poem tend to appear in the mbeling poem initiated by Remy Sylado in the 1970s. Mbeling poetry is a type of poetry that tends to come out of the rules of writing a poem that prioritizes freedom in writing poetry. The human issues expressed in mbeling poetry are issues experienced by human beings in daily life both in the work, society, creation, human relationships with other human beings, human relationships as social beings, and human relationships in the container as part of the nation and state. Issues concerning economics, politics, law, and rules are also studied in mbeling poetry. Pradjoko (2012:2) a literary work is an imaginative work of the author that composes the 'reality of life' which he created in a literary work.

The distinctiveness of mbeling poetry as one of the creations of poets and portraits of the state of human problems recorded in it is important to be analyzed in this study. Structurally mbeling poetry tends to free itself from diction, rhyme, rhythm, and become 
interesting to study. This freedom certainly has its own peculiarities in the form of poetry. As in the poem entitled Remy Sylado's "Kesetiawakanan Asia-Afrika" poetry that tends to engage the reader to think, and drain the emotions of being stuck from a fulgar view of undressing, changing clothes at the same time, but at the end of the poem it is explained that the places are different Mei Hwa at Taipeh and Farouk in Cairo. Other poems such as "Naluri Hayati Iwan dan Tuti" which embodies the action of a creature who is infected with lust to have intercourse. The story of Iwan and Tuti in the poem seemed to give a fulgar image of the process of being who is not ashamed to be expressed in a language that is simple and understandable to the reader. But at the end of the poem it is revealed that Faith is the name of the male dog while Tuti is the name of the female dog. In addition to romance and a pair of mbeling poetry creatures also criticize the poet who is considered already established in eranya such as poetry titled "Di Blok Apa?".

Based on the problems that have been described, in this study the researchers focused on the topic "Human Problems in Poetry Mbeling Work Remy Sylado: Strata Analysis Norms Ingarden". The purpose of this study first, describe the structure of Remy Sylado's mbeling poem. Secondly, knowing the human problems in Remy Sylado's mbeling poem.

\section{Method}

This research uses descriptive qualitative research method. Data obtained from the collection of Remy Sylado mbeling poems published by KPG (Kepustakaan Populer Gramedia) in 2004. Data analysis used the theory of strata norm analysis of Ingarden.

\section{Results and Discussion}

1. The Structure of Mbeling Poetry by Remy Sylado

\section{a. Votes}

Asonance and alliteration are contained in poems such as mbeling in poetry "Lebih Baik Mati Muda" where each verse has anonymity and alliteration. The first line of the first line "Jika usia menua kapan waktu" show assonance $a$ and alliteration $k$. Second line "dan aku tak berani menulis puisi" show assonance $a$, $i$, and alliteration $n$. Third row "dengan jendela yang dibuka lebar" show assonance $a$ and alliteration $n$. Fourth row "melihat kenyataan yang memerintah" show assonance $a$ and alliteration $n$. Fifth row "tentang kebusukan yang memerintah" there is assonance $e, a$, and alliteration $n$. Sixth row "tentang kesemenaan yang berkuasa" there is assonance $e, a$, and alliteration $n$. Row seventh "tentang korupsi yang memimpin" there is assonance $i$ and alliteration $n$. Eighth row "tentang penindasan hak asasi" there is assonance $a$ and alliteration $n$. The ninth row "Lebih baik aku mati muda", there is assonance $a$ and alliteration $b, k, m$.

Asonance and alliteration are also found in poetry "Jawa \& Melayu". The first verse of the second line "tahu betul" there is assonance $u$ and alliteration $t$. Third row "bahwa panggilan" there is assonance $a$ and alliteration $n, g$. Fourth row "anak laki di Jawa: tole" there is assonance $a$ and alliteration $k, l$. Fifth row "berasal dari bahasa Jawa: kontole" there is assonance $a$ and alliteration $b, r, s$. The use of asonance and alliteration in Remy Sylado's mbeling poem makes poetry interesting, clearly understood and shows that poetry is able to be presented with no rules but still presenting beauty in poetry.

\section{b. Layer of meaning}

Pradopo (2009:17) reveals the smallest unit of phoneme. The phoneme

units are syllables and words. Words combine into groups of words, sentences, paragraphs, verses, chapters, and whole stories. They are all units of meaning. In the collection of Remy Sylado mbeling works of poetry there is a majas or style of language used by poets both conscious and unconscious to make mbeling poetry becomes more meaningful. Majesty of irony has the greatest amount of usage in mbeling poetry. The mantle of irony is the master who expresses contradictory meanings, with the intent of mocking (Tarigan, 2009:61). Major irony in poetry "Nymphomania Jeng Sri" as in the fifth stanza the tenth line of the eleventh row "bini pating tletek sak nggonnggon/Makanya orang menyebutnya lonte lanang/memegang aji-aji Gunung Wilis:" The mantle of irony is also found in the seventh verse of the seventh verse "Hakim menunjukkan foto besar Suharto/sambil bertanya, "Wajah siapa ini?"/Jawab Encek Peng Kun dengan lugunya/"Hayya, semua olang tahu la, itu sukalno.". The innuendo of men who have more than one wife tend to experience gossip because it is considered unnatural and tend to negative. 
Table 1. The use of masterpieces in Remy Sylado's Mbeling Poem.

\begin{tabular}{lll}
\hline No. & $\begin{array}{c}\text { Language } \\
\text { Style }\end{array}$ & Amount \\
\hline 1 & Irony & 46 \\
2 & Climax & 22 \\
3 & Parable & 15 \\
4 & Sarcasm & 15 \\
5 & Alliteration & 13 \\
6 & Parallelism & 8 \\
7 & Correction & 7 \\
8 & Parallelism & 5 \\
9 & Polysindeton & 4 \\
10 & Metaphor & 2 \\
11 & Anti climax & 2 \\
12 & Litotes & 2 \\
13 & Satire & 2 \\
14 & Personification & 1 \\
15 & Apofasis & 1 \\
16 & Inuendo & 1 \\
17 & Pleonasme & 1 \\
18 & Eufimism & 1 \\
19 & Cynicism & 1 \\
20 & Hyperbole & 1 \\
& AMOUNT & 150 \\
\hline
\end{tabular}

\section{1) Diction}

Diction can be interpreted as a choice of words by the author in his work. In this context the notion of denotation and connotation should not be ignored. Denotation is a logical meaning, which corresponds to a dictionary, whereas connotation is the meaning of the kias, which is associated or suggested (Al-Ma'ruf, 2010:29). Kridalaksana (2009:50) explains diction is a choice of words and clarity of pronunciation to gain a certain effect in public speaking or in coral-fabricating.

The poet uses various languages in the selection of mbeling poems such as the use of Javanese, Manado, English, Arabic, Malay, Sundanese, Manado, Turkish, Japanese, French, Greek, Greek. The poet uses words in various languages such as (tole, tempik sorak, kluruk, kongkorongok, bakuku, kukuyu, crow, Nijmegen, kraaien, krahen, chant du coq) to stimulate the reader's imagination to understand the intentions conveyed by the poet.

\section{c. Third Layer}

Pradopo (2009:18) explains the layers of meaning creates a third layer, in the form of objects that are proposed, the background, the performer, and the author world. The object of mbeling poetry in general. The poet tends to place his position on the third actor in a collection of Remy Sylado's mbeling poems. There are a number of a total of 141 poems there are 111 poems that put the poet's role as a poet is the her (the third actor). This role makes the poet's discretion in conveying ideas, ideas, and thoughts in creating. Background places tend to exist in every mbeling poem. This implies that mbeling poetry tends to convey a message somewhere in accordance with the role, function, value, and usefulness contained in the background of the place in the poem. The contents of mbeling poetry in general about unfinished life problems to be solved by humans and tend to harm human rights in creating, living, and community.

\section{d. Fourth Layer}

Unreported "world" layers, but already implicit, appear as follows. Mbeling poetry presents about the problems that exist in the world such as family problems, community, nation, state, and unstoppable life fluctuations in real life. The dynamics of problems in mbeling poetry is usually packed through the use of a particular language or style. This style of language contains a particular image or description that describes something that the reader can feel or understand. As with poetry "Sajak Sanjak" the fifth stanza is an intellectual image. Al-Ma'ruf (2010:56) describes the imagery produced through intellectual associations called intellectual imagery. In the fifth stanza /kita sering berangan rencanalterbang dalam kereta kencana/berjuang untuk tanda lencana/tapi berakhir dengan bencanal (Sylado, 2004:139). The desire to achieve something tends to run through obstacles and end in failure. But such a struggle must be an experience that later became the material of contemplation to perform the next activity. The description of the struggle to achieve this goal seems to make the reader get a picture of someone who is reaching the goal.

\section{e. Fifth Layer}

Pradopo (2009:19) reveals the fifth layer is a metaphysical layer that causes the reader to contemplate. The theme contained in the mbeling poem tends to be about social criticism that puts forward the problems in society both in general and in particular. Criticisms that tend to be given to criticize the situation that is considered no progress, does not provide a fair 
space to create and open a new view in addressing issues that are too profitable rulers of the time.

\section{Human Problems in Poet Sylado's Mbeling Poem}

Human problems written on mbeling poems such as social aspect, humanity, freedom of expression attached to mbeling poem. Social aspects such as human relationships with other human beings in life reflect conditions that are not relevant to freedom of speech, there is injustice in cultivate element of reformer that can be used as a finding to refresh the state that tends to static. The human aspect of human nature that tends to stick to itself and affect the character or traits of human personality. Mbeling poetry presents humanitarian problems of displeasure, disagreement, and disrespect to circumstances that harm humans either directly or indirectly. Freedom in expression in the form of problems that work, innovate, and bring up poems that tend to differ in the era and era. The existence of different views between the writing style of the established poet and young poet is a process through which to bring up a new form of poetry. As with poetry "Seorang Emak Ungkluk di Ciroyom Membujuk Ujang yang Menangis dalam Sebuah Bilik Rumah Pelacuran" which describes the actions of a child who has done a bad deed and asked to return to the right path. A mother's struggle to steer her child from a bad path to the path of kindness is a tireless struggle. Another problem in the mbeling poem is the problem of romance, as in poetry "Cintaku Tati" who describes the twists and turns of love from affection, hate, boredom, and ends in a quarrel.

\section{Conclusion}

The structure of mbeling poetry has a distinctive characteristic that is to free itself from the rules of writing poetry. This peculiarity occurs because mbeling poetry is able to be present in an age that tends to stagnate. The problem contained in the mbeling poem is a form of description of the complex world life and there is an imbalance between freedom from expression and existence. Through the ability to present the form, structure, and human problems that are packed with simple language, the presence of mbeling poetry until now still exist and consciously or unconsciously used by human in conveying ideas, ideas and criticism.

\section{References}

Al-Ma'ruf, Ali Imron. 2010. Kajian Stilistika Perspektif Kritik Holistik. Surakarta: UNS Press.

Pradopo, Rachmat Djoko. 2009. Pengkajian Puisi. Yogyakarta: Gadjah Mada University Press.

Pradjoko, Didik. 2012. Peristiwa Sekitar Krisis Nasional 1965 sebagai Latar SosialPolitik dalam Karya Sastra Indonesia 1966-1974: Kajian Awal Atas CerpenCerpen dalam Majalah Sastra dan Majalah Horison. Jurnal Jentera Volume 1 Nomor 1. Jakarta: Badan Pengembangan dan Pembinaan Bahasa Kementerian Pendidikan dan Kebudayaan.

Sugiarti. 2013. Representasi Identitas dan Etnisitas Minang dalam Novel Persiden Karya Wisran Hadi. Jurnal Jentera Volume 2 Nomor 2. Jakarta: Badan Pengembangan dan Pembinaan Bahasa Kementerian Pendidikan dan Kebudayaan.

Sylado, Remy. 2004. Puisi Mbeling Remy Sylado. Jakarta: Kepustakaan Populer Gramedia.

Tarigan, Henry Guntur. 2009. Pengajaran Gaya Bahasa. Bandung: Angkasa.

Waluyo, Herman J. 2010. Pengkajian dan Apresiasi Puisi. Salatiga: Widya Sari Press. 